\title{
Modelling the structural changes in vegetation under different grazing regimes
}

\author{
D.C.P. Thalen, H. Poorter, L.A.P. Lotz \& P. Oosterveld
}

\section{Detailed contents}

1. Introduction

1.1 Grazing as a management practice for conservation

1.2 Pattern development under grazing $\ldots \ldots \ldots \ldots, 168$

1.3 The reasons for a modelling approach ...... 169

1.4 Non-applicability of existing models...... 170

2. Some basic concepts and premises .......... 171

2.1 Vegetation structural classes and succession $\ldots \ldots \ldots \ldots \ldots \ldots \ldots \ldots \ldots \ldots \ldots, 171$

2.2 Impact of large herbivores . . . . . . . . 172

3. The matrix model MAT ............. 172

3.1 Structure of the model . . . . . . . . . . . 172

3.2 Assumptions and input ............ 172

3.3 Examples of results of simulations ........ 174

\section{Introduction}

\subsection{Grazing as a management practice for conser- vation}

Most grasslands and other areas with a short herbaceous vegetation in The Netherlands will, without grazing or cutting, follow a succession towards woodland. This fact is of crucial importance to all managers of conservation areas who wish to maintain or create diversity in short vegetation, and is now usually recognised in the management of nature reserves. Most of the grasslands currently managed by conservation agencies in The Netherlands were previously grazed or mown for hay. Under these practices, sometimes continued for centuries, a semi-natural landscape developed with a great variety of habitats, rich in plant and animal species.

J. van Andel et al., (eds.), Disturbance in Grasslands. ISBN 90-6193-640-3. (C) 1987, Dr W. Junk Publishers. Dordrecht. Printed in the Netherlands.
4. The production-consumption model PROCOS ... 174

4.1 Structure of the model $\ldots \ldots \ldots \ldots \ldots \ldots \ldots .174$

4.2 Assumptions and input ............ 175

4.3 Examples of output ............... 176

4.4 Sensitivity analysis $\ldots \ldots \ldots \ldots \ldots \ldots \ldots, 177$

5. Application of the modets ............. 178

5.1 General...................... 178

5.2 The Borkener Paradies case: an attempt of validation .................... 179

5.3 The Oostvaardersplassen case: an early use of the prediction possibilities . . . . . . . . 180

6. Further development, improvements . . . . . . . 180

7. Summary and conclusions $\ldots \ldots \ldots \ldots \ldots \ldots \ldots \ldots 181$

Acknowledgements $\ldots \ldots \ldots \ldots \ldots \ldots \ldots \ldots \ldots \ldots, 182$

References ....................... 182

The situation has changed in the past decades with the introduction of artificial fertilizers and the mechanical means to lower the groundwater table. That has allowed more intensive grazing and mechanical harvesting, resulting in a drastical reduction in the floristic and micro-structural diversity of the Dutch grasslands.

The nature conservation agencies, both governmental and private, are now attempting to restore the diversity of grasslands under their control. Grazing animals have proved to be promising tools in the conservation or even creation of diverse habitats (Thalen, 1984a; Oosterveld, 1985). Experience has shown that two conditions should be met in the management of nature reserves (e.g. Westhoff, 1971, 1977):

1. the management should lead to a spatially varied but (in time) constant influence, and

2. the type of influence should not be alien to the system. 
Three, more practical, aspects of management might also be taken into account:

3. it should be applicable to areas of different size,

4. it should be economically feasible,

5. the 'tools' to be used should be fitting in the landscape (scenery).

There is ample evidence that large grazing animals, both domestic and wild, if properly chosen in terms of species and densities, can be useful management tools (Oosterveld, 1975, 1985; Van de Veen \& Van Wieren, 1980; Bakker et al., 1983; Thalen, 1984a). This is now widely recognised in The Netherlands. Some 35 conservation areas were grazed by domestic animals (cattle, horses, ponies, sheep and goats) in 1971. This number has increased by more than tenfold since then.

\subsection{Pattern development under grazing}

In their search for food, water, and shelter, herbivores select areas in their daily pattern of activities. From the larger to the smaller units choices are made between landscapes, plant communities and, especially where food is concerned, between plant species and parts of individual plants (e.g. Pratt et al., 1986). Each individual animal acts according to its physiological and social status, but there are also fairly constant differences between species. For example 'grazers' (bulk and roughage feeders), 'browsers' (concentrate selectors) and 'intermediate feeders' (versatile feeders able to adapt their diet) have been recognised (Hofmann, 1973, 1976; Van de Veen, 1979; Van de Veen \& Van Wieren, 1980). Depending on whether an animal is a 'grazer' or a 'browser' there is a preference for different types of vegetation resulting in a different impact of the foraging animal on the vegetation and the terrain (e.g. Putman, 1986).

The behaviour of cattle, ponies, sheep, and goats has been studied in a number of nature reserves in The Netheriands. It was found that a more or less fixed utilization pattern is soon established. Moderate to low stocking rates are usually applied, but a relatively small part of the terrain is always used very heavily, while in more than half of the area the animals may rarely be seen (Table 1 ). The daily routine of terrain use is partly governed by the availability of drinking water and shelter or of favoured resting places, partly also by the locations where preferred forage is available. Areas previously grazed will be revisited regularly to harvest the regrowth of young shoots of high palatability and nutritive value; this leads to a mosaic pattern of heavily used and virtually unused vegetation. A pattern of the levels 'land unit', 'between community' and 'within community' can be distinguished (Oosterveld, 1976; Bakker et al., 1984; Hillegers, 1984; Putman, 1986). If the grazing management is stable, this pattern will be enhanced; areas of short herbaceous cover will be maintained, while the ungrazed areas follow a succession via tall grasses and forbs and shrub and tree establishment to woodland and forest. The first phases of such successions can now be observed in many nature reserves in The Netherlands that have been grazed by large herbivores (Oosterveld, 1985; Fig. 1).

Table 1. Intensity of terrain use (\%) in two nature reserves, where grazing with large domestic animals is used as a management tool for conservation. The figures were calculated from presence scores, carried out continuously two days a month over a full year (from: Oosterveld, 1979). Grazing pressure (in number of cattle or horses per hectare): intensive - 1.0 or more; normal - 0.3 to 1.0 ; extensive -0.1 to 0.3 ; very extensive -0.1 or less.

Type of terrain and type of grazing

Grazing pressure

Intensive Normal Extensive Veryextensive

Cattle and horses in a saltmarsh, low dune area,

360 ha, 1 animal per 3 ha, seasonal grazing

6

12

57

25

Icelandic ponies in abandoned fields, heathland, pine plantations, area $100 \mathrm{ha}, 1$ animal per $5 \mathrm{ha}$, permanent grazing

3

10

60

27 
A

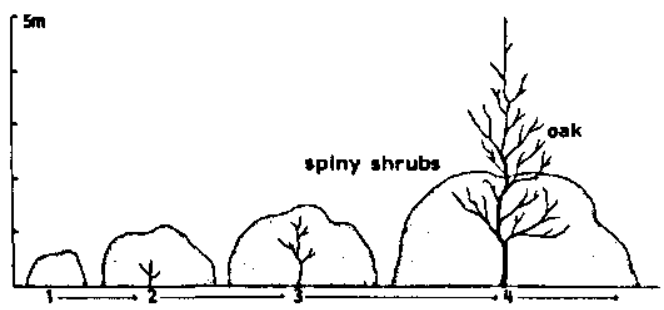

B

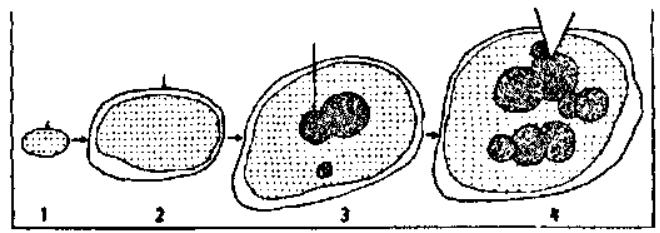

c

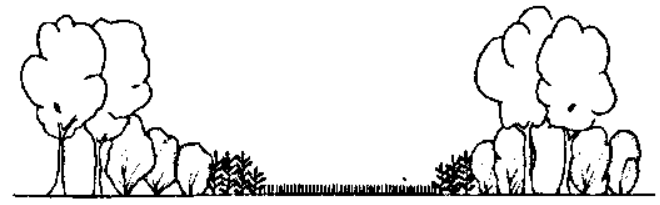

Fig. 2. The establishment of trees within the protection of unpalatable species (a, b), and the resulting physiognomy (c) of the vegetation as observed in the Borkener Paradies. The vegetation has been extensively grazed for many years by cattle (see 1.2 and 5.2). From Burrichter et al. (1980).

Convincing examples of all the phases of succession and the final dynamic equilibrium can only be seen in areas with a very long history of stable and not too intensive grazing, for example in the New Forest in England (Putman, 1986) and on the 'Alvar' (calcareous heath) areas of the Swedish islands Oland and Gotland (Petterson, 1965; Sjögren, 1970; Rosen \& Sjögren, 1973). Probably the most thoroughly analysed and well described area is the 'Borkener Paradies' in north-west Germany (Burrichter et al., 1980; Jaspers, 1983; see also 5.2). Quercus robur develops here under the protection of such unpalatable species as Prunus spinosa, Rhamnus catharticus, Crataegus spp., Rosa canina and Rubus spp. (Fig. 2).

The changes in vegetation structure caused by selective grazing, trampling, and manuring are followed by changes in the plant species composition (Van de Laar \& Slim, 1979; Bakker et al., 1983; Bakker et al., 1984). Relatively little research has been done on changes in the fauna under extensive grazing. Some information is avail- able for the 'Cranendonck' area, shown in Fig. 1, where rabbits (Oosterveld, 1983), earthworms (Eijsackers, 1983) and mice (Table 2) have been studied. There is strong evidence of increasing species diversity of the mesofauna and macrofauna, directly following the changes in vegetation structure and increasing plant species diversity (Van de Laar \& Slim, 1979).

\subsection{The reasons for a modelling approach}

Research on grazing as a means of creating and maintaining habitat or species diversity in nature reserves with grasslands and other short vegetation types started at the Research Institute for Nature Management (RIN) in the early seventies. Similar studies were soon taken up by a number of university departments, in a cooperation with RIN, in particular the Department of Plant Ecology of Groningen University and the Department of Nature Conservation of the Agricultural University in Wageningen (Thalen, 1984b).

After a decade of study certain generalisations could be made. It then became apparent that a modelling approach to simulating changes in vegetation macrostructure under grazing would be very useful. The main reasons for such a modeling approach are:

a) to gain further insight into the structure and

Table 2. Developments in small-mammal populations as tecorded by trapping in the Cranandonck area, and area continuously grazed since 1972 (see text of Fig. 1 and 1.2). From data collected by P.A. Slim.

\begin{tabular}{lcc}
\hline Species & \multicolumn{2}{c}{ Years when the trapping } \\
& $\begin{array}{l}\text { was carried out } \\
1974,1976,\end{array}$ & 1980,1981, \\
& 1977 & 1982 \\
\hline Apodemus sylvaticus & 77 & 75 \\
Microtus arvalis & 23 & 5 \\
Microtus agrestis & 0 & 12 \\
Sorex araneus & 0 & 6 \\
Sorex minutus & 0 & 1 \\
Clethrionomys glareolus & 0 & 1 \\
Total no. of traps set & 2555 & 2795 \\
Total no. of animals trapped & 56 & 101 \\
\hline
\end{tabular}




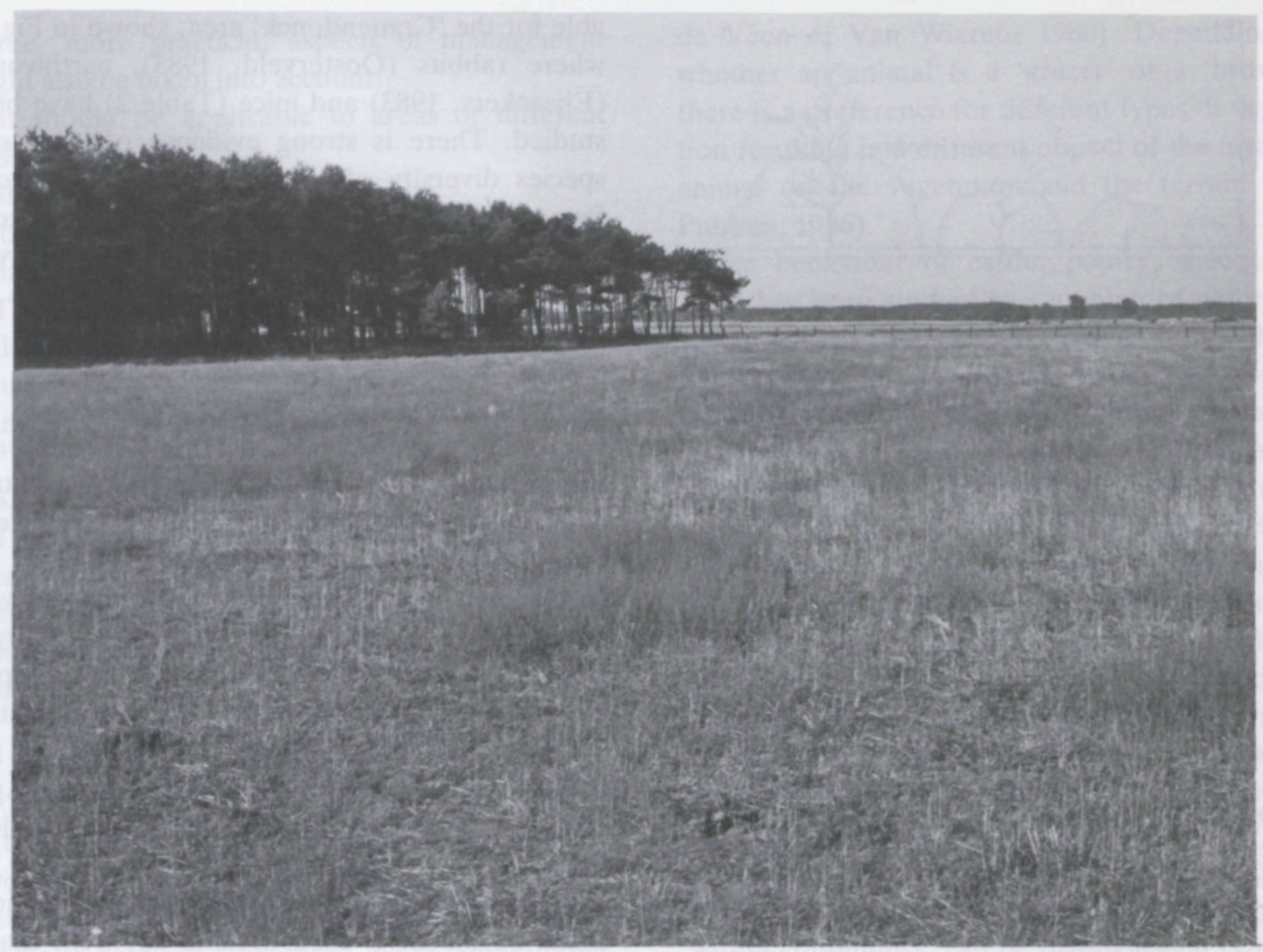

Fig. 1. Vegetation development on former arable fields between 1973 (above) and 1982 (next page) in the Cranendonck area, a reserve of some 100 ha with approximately equal areas of formerly arable fields, Pinus plantations and dry heathland with driftsands. The area has been extensively grazed by Icelandic ponies since 1972 (see Oosterveld, 1985).

functioning of the system by recognising the apparently essential processes;

b) to identify gaps in the available knowledge;

c) to develop methods for the systematic and objective prediction of the long-term effects of different grazing regimes;

d) to demonstrate to administrators and reserve managers the probable consequences of various grazing management practices.

\subsection{Non-applicability of existing models}

A review of already existing and published mathematical models which simulate grazing systems soon showed that most work had been concerned with the effects of management practices on animal production (Breymeyer \& Van Dyne, 1980; Christian, 1981). Wherever vegetation changes were involved, the central themes were primary production and biomass rather than vegetation structure (e.g. Noy-Meir, 1978; Parton \& Risser, 1979). Most published studies dealt with interactions between large herbivores and grassland. In some cases, microstructural characteristics, related to the morphology of the grass cover, were considered (e.g. Coughenour et al., 1984), but no models were suitable for our needs of treating changes in the macrostructure of vegetation and for a terrain as a whole. The matrix model published by Redetzke \& Van Dyne (1976) provided a useful example of a first crude approximation.

The 'Elephants-trees-grass-grazers' model of Van Wijngaarden (1985), developed as part of a study of the Tsavo ecosystem in Kenya, closely approaches the objectives of this study. This work was published after the results of our mod- 


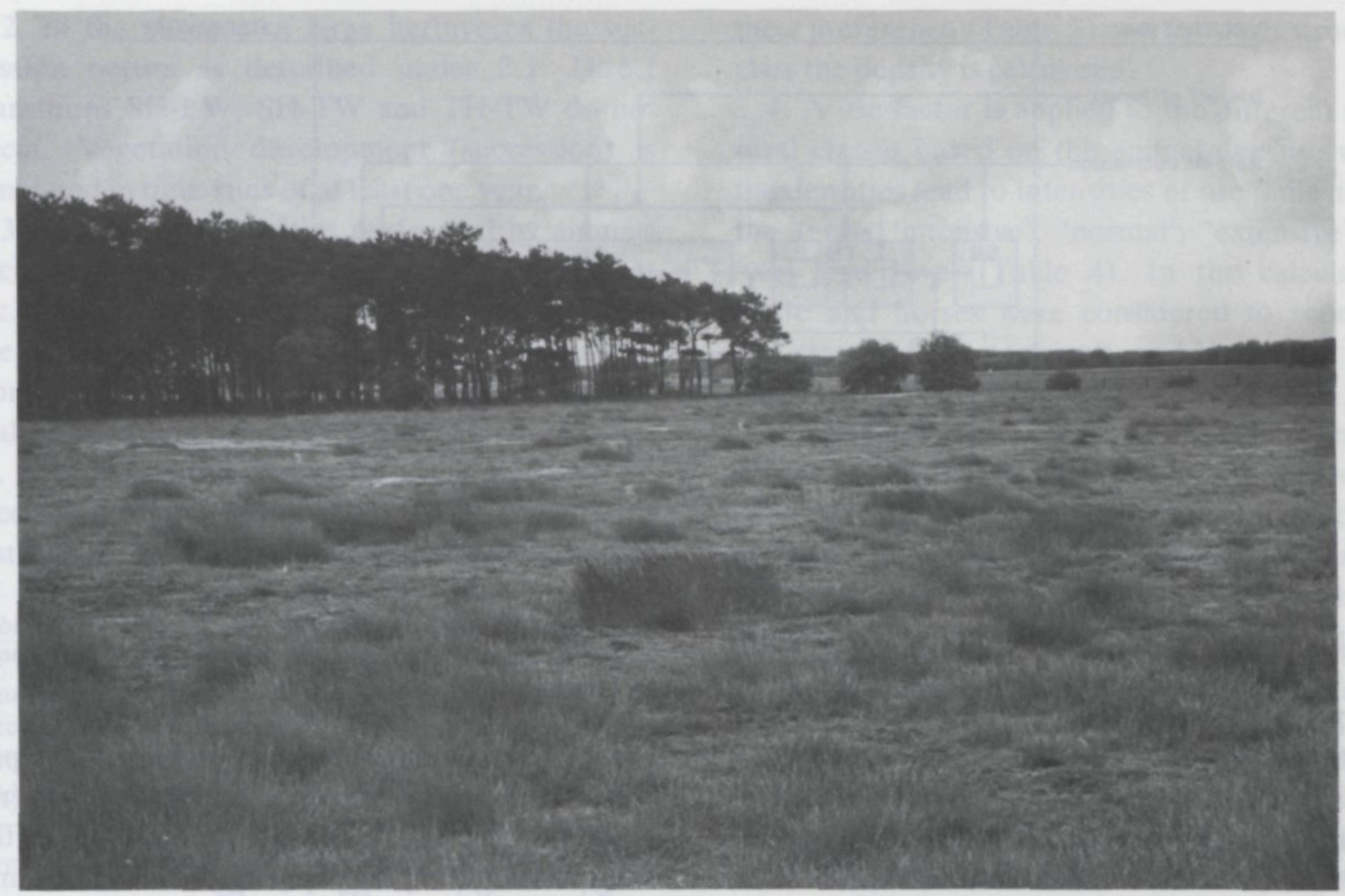

Fig. 2. Physiognomy of the vegetation as observed in the Borkener Paradies. The vegetation has been extensively grazed for many years by cattle (see Burrichter et al. 1980).

elling, as presented hereafter, had been completed. Van Wijngaarden's model concentrated on the long-term consequences of increasing elephant density on the structure of the vegetation (total woody cover, tree cover, shrub cover and perennial grass cover) and on other grazers and browsers. His graphical output closely resembles the output of our models. The present paper describes the development and structure of two simple models (the matrix model MAT and the analytical model PROCOS) and results obtained sofar from these models.

\section{Some basic concepts and premises}

\subsection{Vegetation structural classes and succession}

In the absence of grazing a number of structural classes can be distinguished in the succession from grassland to forest (see 1.2). Four main classes are recognised here (Fig. 2):
SH - short herbaceous vegetation of grasses and forbs, height $<25 \mathrm{~cm}$;

$\mathrm{TH}$ - tall herbaceous vegetation of grasses and forbs, height $>25 \mathrm{~cm}$;

LW - low woody vegetation dominated by shrubs * and small trees, height $<2 \mathrm{~m}$;

TW - tall woodland and forest, height $>2 \mathrm{~m}$.

It is assumed that, without interference (e.g. by large herbivores), natural succession will follow the sequence SH-TH-LW-TW. A forest area may die off after some time under these conditions and return to one of the herbaceous structural classes, after which a new start of a succession sequence takes place.

The vegetation structure of any terrain can be described quantitatively by the percentage area under each of these structural classes. This can generally be achieved using aerial photographs; for example in The Netherlands stereo-cover is available at a scale 1:20,000 or larger. 


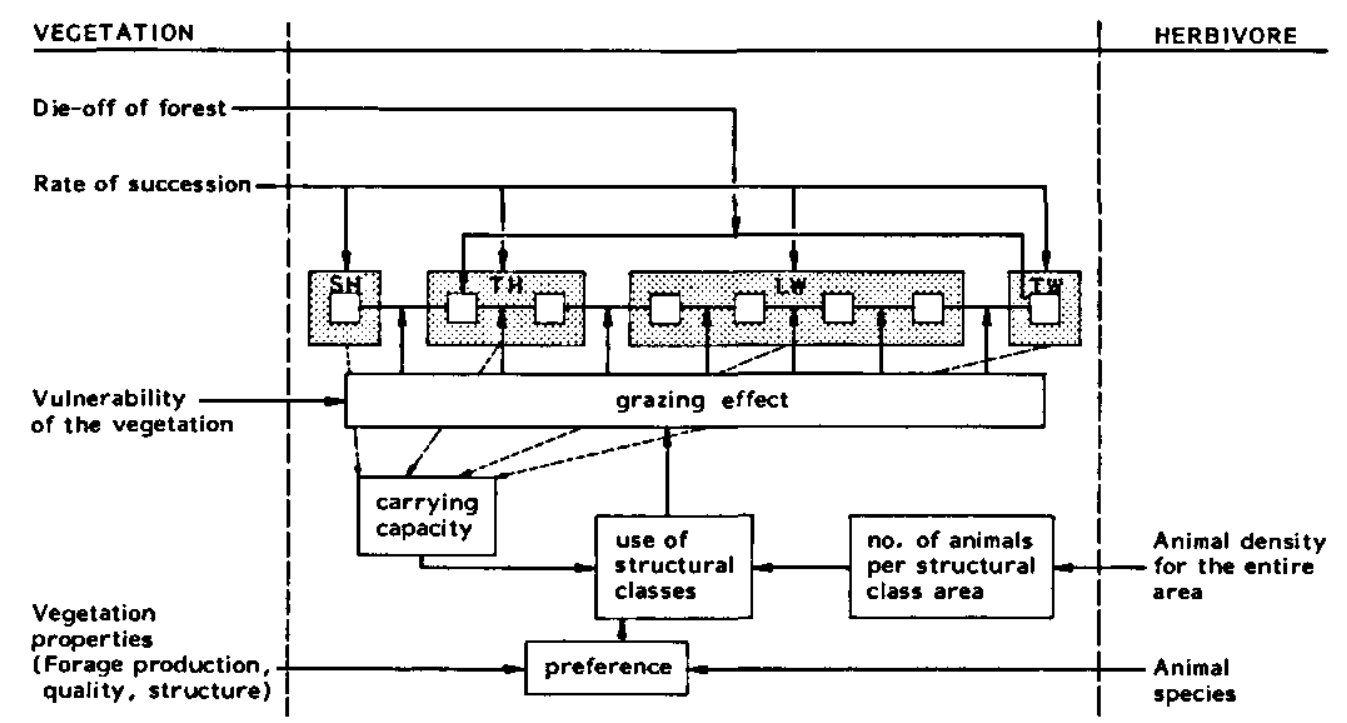

Fig. 3. Schematic presentation of the relations included in the MAT model. (SH $=$ short herbaceous vegetation, $\mathrm{TH}=$ tall herbaceous vegetation, $\mathrm{LW}=$ low woody vegetation, $\mathrm{TW}=$ tall woodland; see 2.1 ).

\subsection{Impact of large herbivores}

There is strong evidence (see 1.2) that large grazers, when released into a terrain with different vegetation structural units, soon develop a fixed pattern of use of that terrain. The difference in use of the various structural units leads to differences in succession. The animals may cause a slow-down, a fixation or even a retrogression in the structural succession sequence described under 2.1. The impact of an animal species will, amongst other things, be governed by its preference for a certain structural type and the animal density (number per unit area). The relative preference of the four main livestock species for the four structural classes, as applied in MAT, was estimated from a large number of observations of animal distribution ( $P$. Oosterveld and others, unpublished, see Table 3).

\section{The matrix model MAT}

\subsection{Structure of the model}

After an exercise with a linear deterministic matrix model (MAT 1, see Lotz \& Poorter, 1983), a non-linear model (MAT 2) was developed. A schematic presentation of the relations that play a role in the simulation is given in Fig. 3. The principle of the matrix model is that in each run (representing a certain time span) the status at time $t+l$ is reached by multiplying the status at time $t$ with a transition matrix. In the non-linear model, the values used in the transition matrix depend, for each run, on the outcome of the many multiplications performed in the previous run. For further details the reader is referred to relevant textbooks, e.g. Jeffers (1978). Matrix models have certain advantages and disadvantages when applied in ecology; for example Jeffers (1982) concluded that '...'reality' is sacrificed to some extent in order to gain the advantages of the particular mathematical properties of the formulation. The deductive logic of pure mathematics then enables the modeller to examine the consequences of his assumptions without the need for time-consuming 'experimentation' on the model'. This applies to the MAT models, expecially to MAT 1 . For MAT 2 the assumptions are given below.

\subsection{Assumptions and input}

1. The vegetation structure of a terrain (total area 1.0) is characterized by four structural classes: SH, TH, LW and TW. SH and TH do not occur under LW and TW. Every structural class has several developmental phases. 
2. In the absence of large herbivores the succession occurs as described under 2.1. Direct transitions SH-LW, SH-TW and TH-TW do not occur. Vegetation development (succession) is simulated in time-runs of at least one year.

3. The various activities performed by animals such as grazing/browsing, trampling, manuring, etc., lead to a change in vegetation structure. The use of the different structural classes is calculated from the preference, which is dependent on animal species and vegetation characteristics (Fig. $3)$. If a certain vegetation type is not present, it receives the preference value 0 . The animals are distributed over the structural types according to

Table 3. The relative preference of four livestock species for the four macrostructural classes, as used in the simulations. Figures indicate presence in a structural class expressed as percentage of time spent in all classes together. $\mathrm{SH}=$ short herbaceous vegetation, $T H=$ tall herbaceous vegetation, $\mathrm{LW}$ $=$ low woody vegetation, $\mathrm{TW}=$ tall woodland (see 2.1 ).

\begin{tabular}{lllcr}
\hline \multirow{2}{*}{ Livestock species } & \multicolumn{5}{c}{ Vegetation macrostructural class } \\
& SH & TH & LW & TW \\
\hline Cow & 80 & 10 & 5 & 5 \\
Sheep & 60 & 20 & 15 & 5 \\
Horse & 60 & 15 & 15 & 10 \\
Goat & 40 & 15 & 30 & 15 \\
\hline
\end{tabular}

their preference (Table 3) and for each structural class the density is calculated.

4. A use factor is applied to the different structural classes based on the animal density, where the densities lead to intensities of use indicated by the terms 'intensive', 'normal', 'extensive' and 'very extensive' (Table 4). In the calculations cattle and horses were considered to represent one standard livestock unit, and sheep and goats one third.

5. Grazing impact depends on both intensitys of use and structural class (Table 5). Three categories of grazing impact on succession are distinguished: heavy impact - will cause retrogression; moderate impact - inhibits succession; light (or no) impact - allows succession to continue to the next phase.

When the density exceeds the carrying capacity of a structural class the excess number of animals is distributed over the other classes according to the preference (Table 3). The model does not yet simulate spatial effects, so does not take into account the spatial distribution of the structural classes.

Table 4. Use factors $(\%)$ of the vegetation macrostructural classes, for five grazing densities, as applied in the simulations with MAT (see text 3.2).

\begin{tabular}{|c|c|c|c|c|}
\hline $\begin{array}{l}\text { Standard livestock units per hectare } \\
\text { of the macrostructural class }\end{array}$ & $\begin{array}{l}\text { Intensity of use } \\
\text { Intensive }\end{array}$ & Normal & Extensive & Very extensive \\
\hline$>1.0$ & 80 & 15 & 5 & 0 \\
\hline $0.3-1.0$ & 20 & 50 & 25 & 5 \\
\hline $0.1-0.3$ & 5 & 15 & 50 & 30 \\
\hline$>0.0-0.1$ & 0 & 10 & 25 & 65 \\
\hline 0.0 & 0 & 0 & 0 & 100 \\
\hline
\end{tabular}

Table 5. Dependence of grazing impact on (1) intensity of use (see Table 4), and (2) vegetation macrostructural class, as presumed in the simulations with MAT; $\mathbf{H}=$ heavy impact, $\mathrm{M}=$ moderate impact, $\mathrm{L}=$ light impact (see text 3.2 ).

\begin{tabular}{llllll}
\hline \multicolumn{2}{l}{ Vegetation macrostructural class } & $\begin{array}{l}\text { Intensity of use } \\
\text { Intensive }\end{array}$ & Normal & Extensive & Very extensive \\
\hline Short herbaceous & (SH) & H & H & M & L \\
Tall herbaceous & (TH) & H & H & M & L \\
Low woody & (LW) & H & M & M & L \\
Tall woody & (TW) & M & M & M & M \\
\hline
\end{tabular}



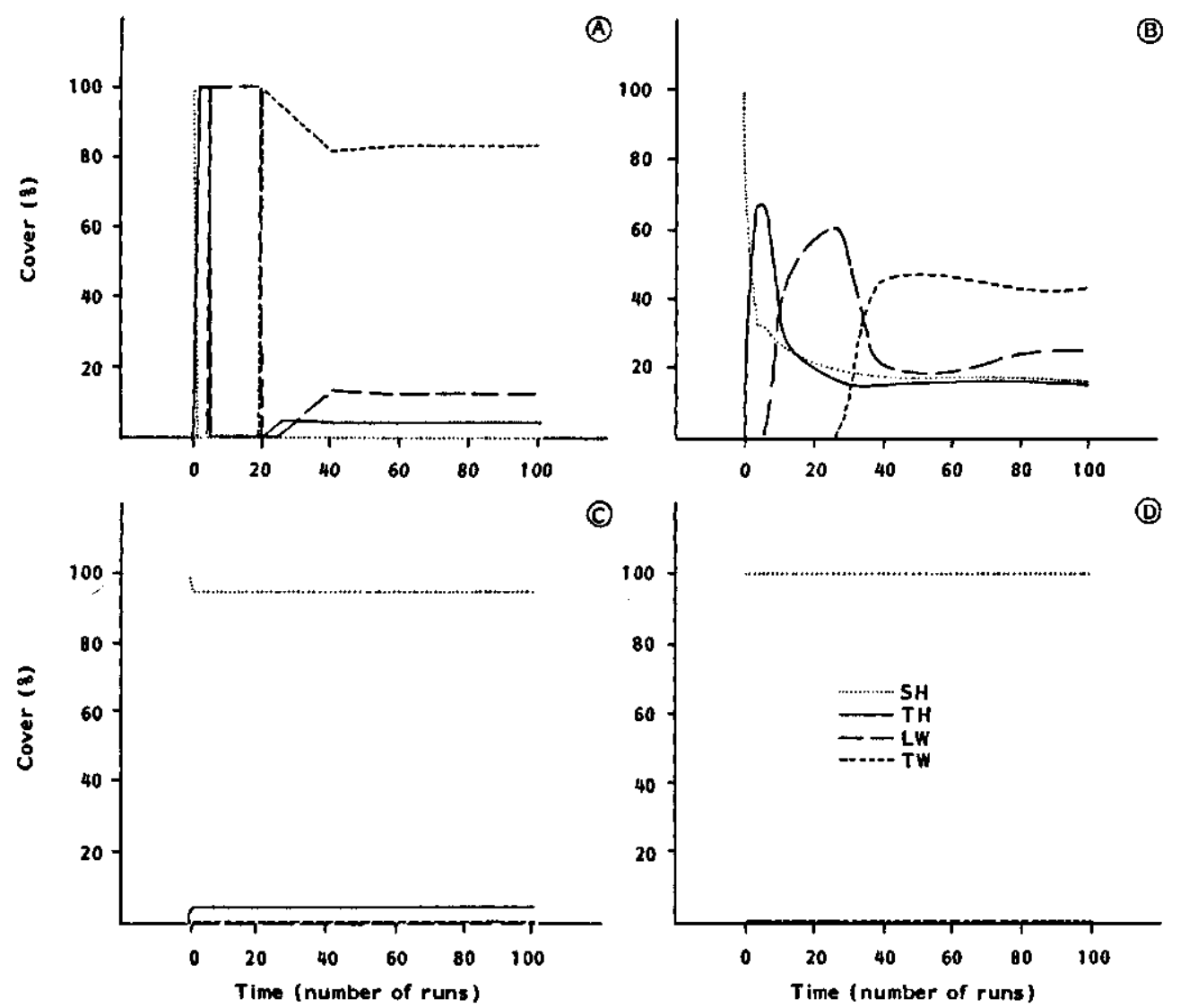

Fig. 4. Results of simulations with the MAT model; vegetation development under different intensities of sheep grazing. Number of animals per hectare: a. 0.0 ; b. $0.5 ;$ c. 2.5 ; d. 5.0 . Start with 100 percent low herbaceous; number of development phases in the structural classes: SH-1, TH-5, LW-15, TW-1. Annually 1 percent of TW changes to TH (die-off of forest).

\subsection{Examples of results of simulations}

An example may clarify the working of part of the model MAT. A terrain with a vegetation structural cover of $25 \%$ each of $\mathrm{SH}, \mathrm{TH}, \mathrm{LW}$ and TW is grazed at a density of one cow per hectare. The preference of cattle for $\mathrm{TH}$ is $10 \%$ (Table 3 ). In this structural class there will be $0.1 / 0.25=0.4$ cattle per hectare. Table 4 shows the use intensity for this density: intensive $20 \%$, normal $50 \%$, extensive $25 \%$ and very extensive $5 \%$. In the structural class TH this leads to the following effects (Table 5: $\mathrm{H}-70 \%, \mathrm{M}-25 \%$ and L-5\%): in one run of the programme $70 \%$ of TH experiences a retrogression in the direction of $\mathrm{LH}, 25 \%$ remains structurally unchanged and $5 \%$ develops in the direction of LW. The results of the simulations can be depicted graphically, e.g. as shown in Fig. 4.

\section{The production-consumption model PROCOS}

\subsection{Structure of the model}

The MAT model has the advantage and disadvantage that all factors affecting vegetation structure during succession are condensed in one operator: the transition matrix. Since matrix models, as mentioned earlier, are only descriptive, they do not satisfy one of the prime reasons of modeling, i.e. to gain an insight in the important processes. With this objective a separate analytical model (PROCOS) was developed.

PROCOS stands for PROduction-COnSumption. The model attemps to clarify the effect of large herbivores on vegetation macrostructural changes by simulating the production of aerial phytomass and its consumption by the animals. PROCOS also distinguishes the macrostructural 


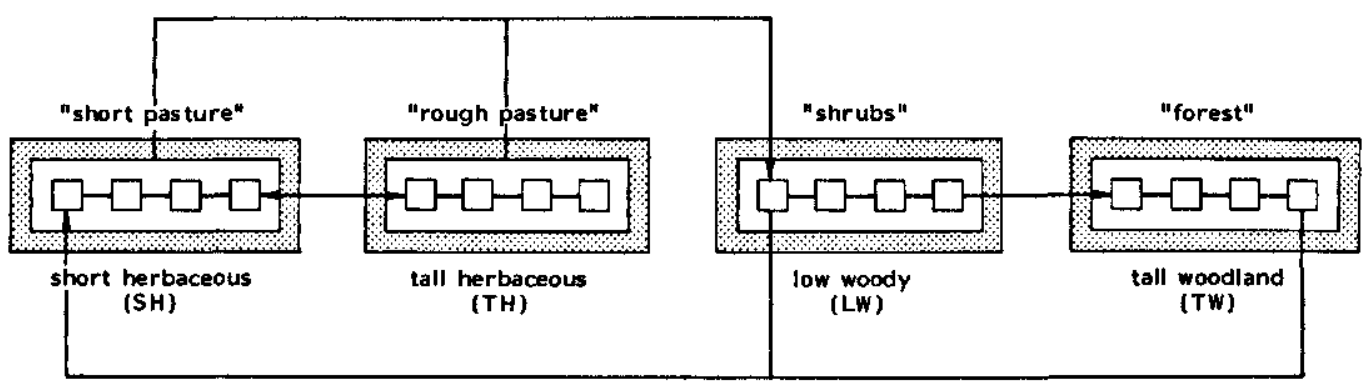

Fig. 5. Schematic presentation of the possibilities of vegetation macrostructural changes as incorporated in the PROCOS model. In the four macrostructural classes development phases (in this case four) are distinguished, each representing a certain standing crop and available forage.

types SH, TH, LW and TW, each divided in a number of development phases (Fig. 5). Each development phase represents a certain above ground biomass (=phytomass) and transitions in development phases take place as a result of changes in biomass. Biomass increment leads to a 'higher' development phase, decrease in biomass through consumption and decomposition leads to a 'lower' phase. The standing crop and its use are central in the reasoning behind the simulation model. Establishment of shrubs and trees may lead to LW and finally TW, forest. Heavy browsing of shrubs may result in a retrogression to herbaceous types, in this model SH (Fig. 5). In PROCOS a correction was also incorporated for the amount of produced biomass lost through animal impact other than grazing in the sense of the defoliation process, e.g. as a result of treading. De Leeuw \& Bakker (1986) used the terms 'foraging' and 'occupancy' to make the distinction. Very little quantitative data exist on loss through occupancy. Estimated percentage values were incorporated, based on personal communications and literature data (e.g. Sonnema, 1974).

The relationships between growth, decomposition and consumption as used in PROCOS for herbaceous vegetation are shown diagrammatically in Fig. 6 . The only difference for woody vegetation is that no unit 'dead material' was distinguished. As seasonal variation in biomass production and grazing pressure had to be incorporated, the time-step used had to be smaller than for MAT. For the simulations presented hereafter a time-step of one month was used.

\subsection{Assumptions and input}

The amount of biomass produced by herbaceous vegetation depends on: (1) amount of live material already present, (2) growth rate, (3) time of the year, and (4) amount of dead material. The same applies for woody vegetation except for a distinction between consumable biomass (leaves and twigs) and non-consumable biomass (e.g. trunks and branches). Death and decomposition take place according to time of the year and several other factors. Summarizing, the following material is available for consumption: herbaceous vegetation: young, old and dead material; woody vegetation: young and old material, and fruits, as far as these are within reach of the animals. For each development phase the amount available for each of these categories is calculated.

The food demands of large herbivores depend

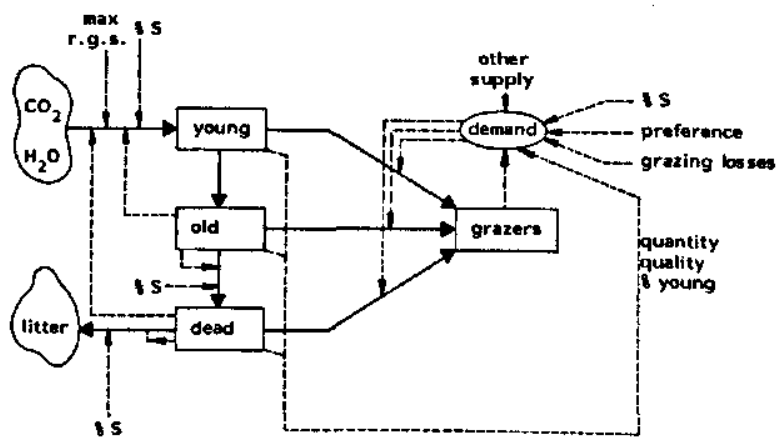

Fig. 6. Schematic presentation of the relations incorporated in the PROCOS model for each of the development phases of the herbaceous classes. $\% \mathrm{~S}=$ seasonal influence, max.r.g.r. $=$ maximum relative growth rate. 


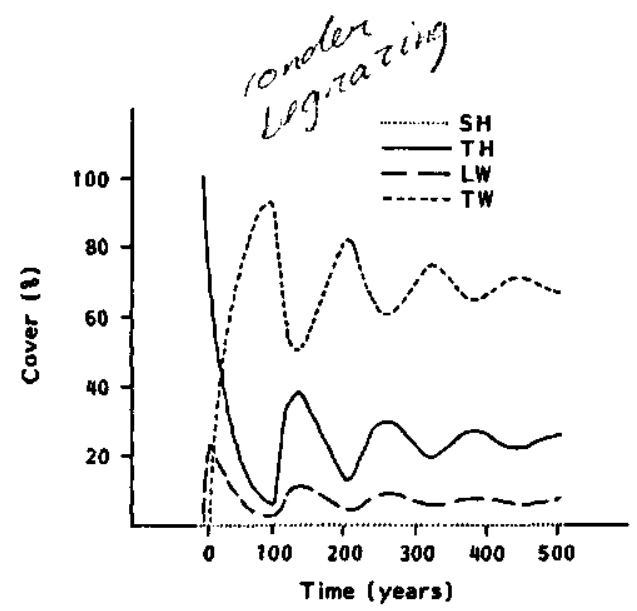

on (1) animal species, (2) density, and (3) time of the year. For the demands an integrated biomass weight unit is used. The consumption of each type of forage for each development phase is dependent on the animal's requirement and preference, the biomass of that type of forage available, its quality and the biomass of the other types of forage in that development phase (for details see Lotz \& Poorter, 1983). Apart from consumption, biomass disappears as a result of trampling and decomposition (see 4.1).

The establishment of woody species occurs in the herbaceous types, depending on area, standing crop, and time of the year. Woody vegetation disapppears through death, at a certain age, of shrubs and trees. Shrubs younger than one year can be consumed and totally removed; older ones can only be partially eaten. For details and further premises the reader is referred to Lotz \& Poorter (1983).

In PROCOS the animal type (grazer, browser or intermediate feeder, see 1.2) is characterized by its annual forage requirement, preference for different types of forage, seasonal pattern of forage requirement, trampling effect, and in a uniformity of grazing in a structural sub-class. Initially the last three factors have been incorporated as constant values or percentage values, because of the lack of reliable data. The values for the annual forage requirements used were taken from the literature (Centraal Veevoederbureau, 1979): horses $3200 \mathrm{~kg}$, cattle $2900 \mathrm{~kg}$, goats 750 $\mathrm{kg}$ and sheep $500 \mathrm{~kg}$. The forage preference values used are shown in Table 6.

Parameter values for vegetation production,

Table 6. Forage preference values of four livestock species for different types of forage, as applied in the PROCOS simulations (estimates by P. Oosterveld).

\begin{tabular}{lrrrr}
\hline Type of forage & \multicolumn{4}{c}{ Livestock species } \\
& Horse & Cow & Goat & Sheep \\
\hline Herbaceous, young & 100 & 100 & 100 & 100 \\
Herbaceous, old & 10 & 10 & 5 & 10 \\
Herbaceous, dead & 1 & 1 & 1 & 1 \\
Twigs, young & 25 & 10 & 100 & 25 \\
Twigs, old & 5 & 5 & 5 & 5 \\
Fruits & 100 & 100 & 100 & 100 \\
\hline
\end{tabular}

Fig. 7.Simulated changes in the macrostructure of the vegetation over a 500 year period, when ungrazed and starting from a low herbaceous vegetation. The data are the result of a simulation using the PROCOS model.

establishment of woody species and available forage from the classes $\mathrm{LW}$ and TW were estimated after a literature search and discussions with experts. Most of these values will differ per terrain type and have yet to be established by measurements in the field (see 6). The assumed values are specified in Lotz \& Poorter (1983).

\subsection{Examples of output}

The graphic output of PROCOS includes changes in percentage cover (relative contribution) and biomass over one year or over many years. The example in Fig. 7 shows for a period of 500 years without grazing the invasion by shrubs (LW), followed by succession to forest (TW). After a century the amount of forest decreases through dieoff and is replaced by LW. Thereafter the amplitude of the fluctuations decreases and at some stage an equilibrium would be established between forest die-off and rejuvenation.

The results of a simulation with two grazing intensities, 0.5 sheep and 1.0 sheep per hectare are shown in Fig. 8a,b. The results at low stocking rate (Fig. 8a) are similar to the ungrazed situation with the same cyclic variation. Since forest (TW) had hardly any palatable material, an increase in TW will lead to an increased grazing pressure on the other classes. Establishment of shrubs (LW) decreases and the existing $\mathrm{LW}$ is so heavily browsed that no new forest develops. Only with 


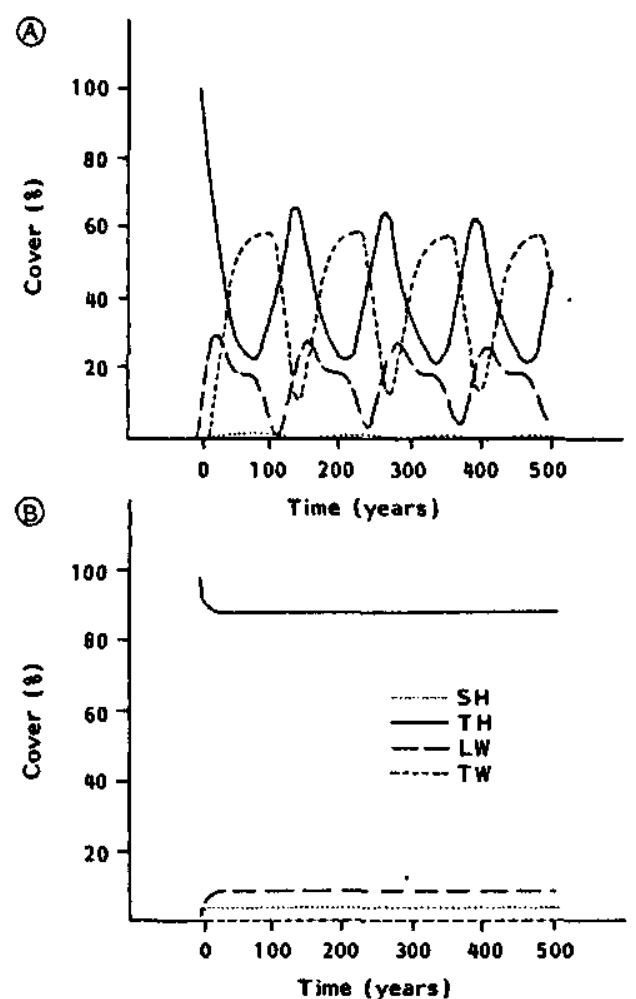

Fig. 8. See Fig. 7. The development under sheep grazing at a density of (a) 0.5 sheep per hectare, and (b) 1.0 sheep per hectare.

the death of trees a new cycle can begin. Under a heavier grazing pressure (Fig. $8 \mathrm{~b}$ ) the shrubs are under such a heavy use pressure that no forest can develop; an equilibrium is reached after 30 years.

The above examples can be used to demonstrate to administrators and reserve managers long/term effects but also serve to demonstrate the temporary nature of some, often unwanted, changes. The common response to such changes is to alter the grazing pressure or introduce other management practices such as mowing of tall forbs or cutting of shrubs. An example of the effect of a change in management is shown in Fig. 9.

An entirely different type of output is the depicting of equilibria finally reached between large herbivores and vegetation, depending on the animal species and density. In case of cyclical changes (e.g. Fig. 8a), average values over a large number of years can be determined, and the equilibria reached, for example under different

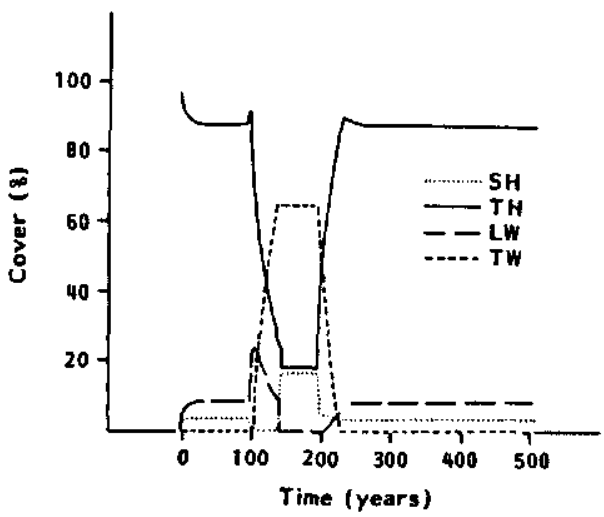

Fig. 9. See Fig. 7. The development under sheep grazing at the following density; yr 0-100: 1.0 sheep per bectare; yr 101-140: no grazing; yr 141-500; 1.0 sheep per hectare.

densities of sheep grazing can be depicted (Fig. $10 \mathrm{~b})$. The increased grazing pressure reduces the percentage of woody structural types, but increases the herbaceous types $\mathrm{SH}$ and $\mathrm{TH}$. The production of herbaceous vegetation increases under extensive use, but decreases under a heavier pressure (Fig. 10a).

\subsection{Sensitivity analysis}

The output of a model depends not only on the assumed relations and mathematical equations, but also on the parameter values used. It is of great value to know how changes in parameter values influence the output of the simulation (Swartzman, 1980). Such a sensitivity analysis can indicate how parameters influence other variables or can define critical components of the system and so indicate the need for further experiments or field measurements. For PROCOS two output variables, not mentioned before, were further evaluated: The Mean Structural Value (MSV) and the Total Available Production (TAP). MSV is the weighted mean of the four main structural classes, reached by multiplying the percentage of the total area with a structural value for each class: $\mathrm{SH} / 0, \mathrm{TH}-1 / 3, \mathrm{LW}-2 / 3$ and TW-1. The analysis was carried out by comparing the outputs when parameter values were changed by 10 percent. To gain an insight into the interactions, in addition an analysis of variance was done 

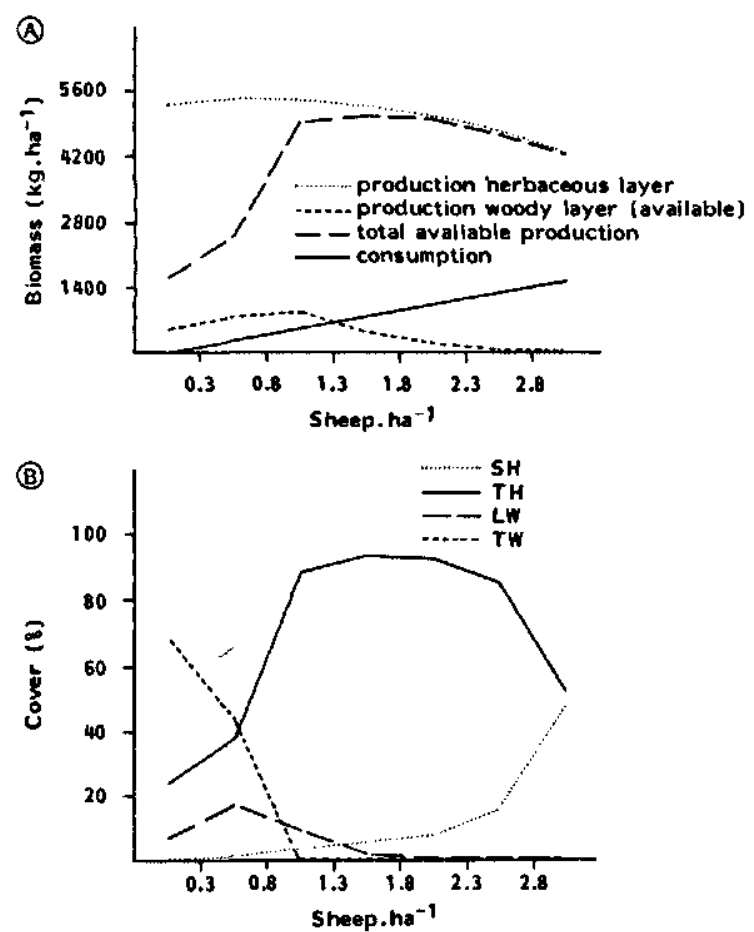

Fig. 10. Results of simulations with PROCOS. The predicted effect of sheep grazing density on the equilibrium values of (a) production of the herbaceous and woody (as far as available to the animal) vegetation, total available forage production and consumption (all in $\mathrm{kg}$ per ha per $\mathrm{yr}$ ); and (b) percentage cover of the four macrostructural classes (see 2.1 and 4.3).

for the perturbations, in a factorial design, of the nine parameters that caused the greatest changes in output. Table 7 gives the main results for these nine tested parameters under two grazing pressures. Under heavy use both, MSV and TAP, are mainly influenced by the relative growth rate of the herbaceous layer and the die-off in this layer. Under extensive use the parameters related to the woody cover are extremely important. The model is relatively stable. The largest deviation from the overall mean can be ascribed to the effect of the herbaceous relative growth rate on TAP and amounts to only $4.2 \%$. All other effects are less. Over $99 \%$ of the total variation is explained by the main and first order effects.

\section{Application of the models}

\subsection{General}

The most immediate value of the presented grazing models is for the management of conservation areas when grazed with livestock (1.1 and 1.2). The models have considerable demonstration value for administrators and terrain managers, particularly in relation to the time spans that should be considered when applying grazing as a management practice. However, if the models are to be used for predictions of developments in a particular terrain, at least two aspects should be considered:

1. valid and reliable values of input-parameters

Table 7. Main results of the sensitivity analysis for the PROCOS model (see text 4.4). MSV = mean structural value, TAP = total available production, both analysed for two grazing intensities. Percentage of total variation explained by one parameter: $+1-$ $=1-5 ;++1--=6-20 ;+++1---=21-100(+$ indicates a positive correlation, - a negative correlation).

MSV

Sheep per ha

0.5
2.0

$++$

$++$

Relative growth rate woody species

Percentage herbaceous dying

Establishment of trees

Percentage wood of twigs/small branches

Maximal loss through grazing

Preference for young herbaceous

Preference for old twigs/branches

Consumption by the animals
TAP

Sheep per ha

0.5

2.0

$\begin{array}{cccc} & +++ & ++ & ++ \\ +++ & -- & +- & - \\ -- & & -- & \\ +++ & & - & \\ & & + & \\ +- & +++ & -\end{array}$


have yet to be collected for a whole range of terrain types

2. the degree of 'reality' of the models (cf. Jeffers, 1982) has yet to be determined by validating the models under various conditions

It is particularly difficult to validate the models because of the lack of quantitative data on vegetation structural development for areas that have been and preferably still are not too intensively grazed and/or browsed by known numbers of large herbivores. In The Netherlands, records are available for less than two decades, yet observations in the field and preliminary results of the simulations show that data for many decades to some centuries are required, mainly because many of the ecosystems under grazing are poor in nutrients and thus succession is slow. An area for which some useful long-term information exists on the effects of grazing on vegetation structural types is the Rorkener Paradies in north-west Germany. A unique opportunity for research and validation may be provided by the grazing management recently imposed on some conservation areas in the newly reclaimed polders with fertile soils. Here successional changes in vegetation structure are fast.

\subsection{The Borkener Paradies case: an attempt of val- idation}

The Borkener Paradies is a conservation area of some $30 \mathrm{ha}$, situated in an old meander of the river Ems, a few kilometers north-west of Meppen in Germany. The area has been under a fairly constant but light summer cattle grazing for many years. The available data were used to run a simulation of vegetation structural development using MAT and PROCOS. The vegetation structural classes, as derived from a vegetation map in Burrichter et al. (1980), were: SH/0.46, TH/0.03, LW/0.08 and TW/0.43. For PROCOS a grazing pressure of 0.3 cattle per hectare from May to October was assumed; for MAT which uses 'annual runs' of continuous grazing, 0.15 cattle per hectare was assumed. The results are shown in Fig. 11a, b. Both model simulations predict an increase in the woody vegetation. It is known that
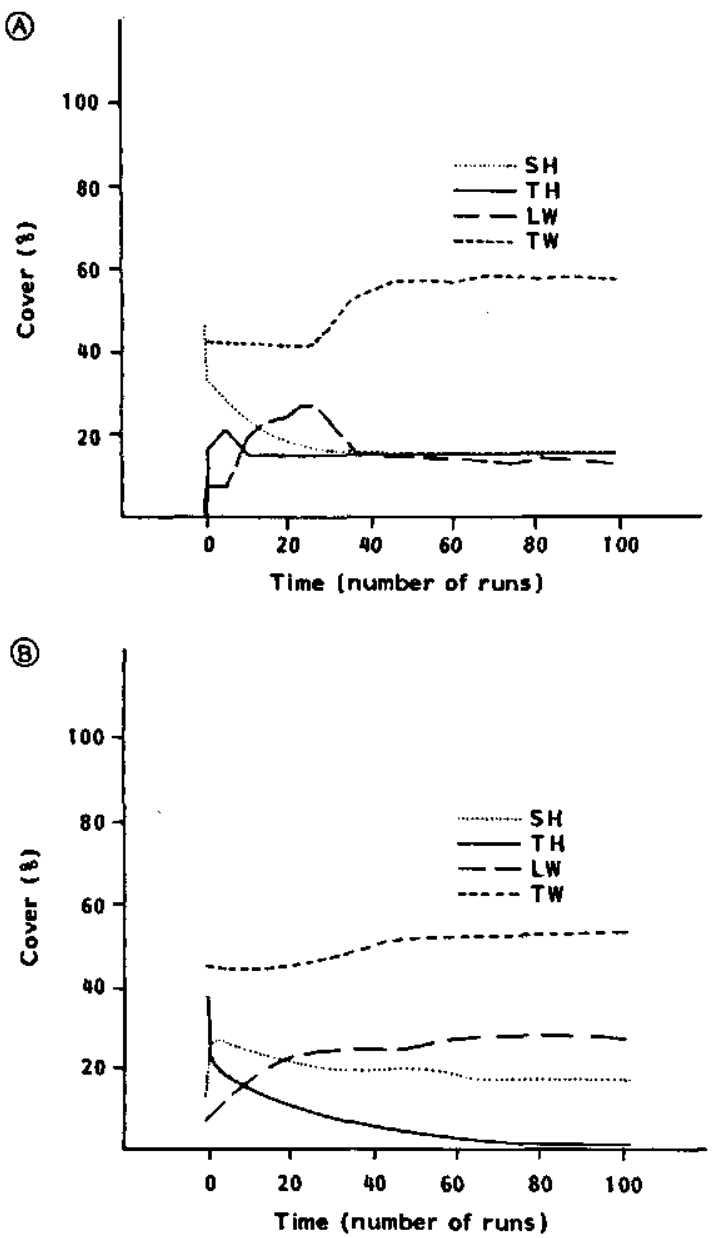

Fig. 11. Simulation of development in the vegetation structure in the Borkener Paradies (see 5.2): (a) results of the MAT model, (b) results of the PROCOS model.

in the past bushes and trees were regularly cut by farmers in order to maintain the open character of the area. A very detailed study on shrub establishment and woodland development was carried out by Jaspers (1983). He estimated an increase in the area under forest of 8 ha over the past 50 years and predicted an increase of another 4 ha in the next 30 years.

The simulation results with MAT and PROCOS are similar to the data collected in the field and found in historic records. This may be as close to a validation as is possible with the available data for any terrain in north-western Europe. However, data from fast-changing areas, such as those found in the new polders, may provide useful validation in the future. 
5.3 The Oostvaardersplassen case: an early use of the prediction possibilities

The Oostvaardersplassen area is situated in Zuidelijk Flevoland, a new polder in the IJsselmeer. In this polder an area of some 6000 ha has been set aside as a nature reserve; an area of 3600 ha is inundated. The area has great nature conservation values, at present especially as a bird sanctuary. In particular large numbers of the Grey lag Goose (Anser anser) use the area. The marsh vegetation, together with the vegetation of the adjacent 2400 ha dyked and drained land, plays an important role in the food supply of geese and othér bird species. The future management of the Oostvaardersplassen as a nature conservation area is of particular concern to the management committee. It is especially important to know how different grazing systems (species, densities, seasonal versus continuous grazing) could be used to maintain a more or less predetermined landscape.

PROCOS was used for a first estimate of the consequences of various management practices. The alternatives for which simulations were run included eight possible combinations of the following three alternative possibilities:

a) continuous (=year-round) versus seasonal

(May-October) grazing with cattle,

b) with and without geese,

c) with and without part of the area inundated for part of the year.

Specially adapted parameter values were used, that could be partly based on data already collected. The geese grazing was treated the same as other grazing, though with adapted parameter values for preference and food requirements. Fig. 12 shows the results for a selection of four different situations.

The results demonstrate the very large number of cattle that would have to be introduced and managed in this reserve, if seasonal grazing with cattle only was applied, and if the desired large area $(70 \%)$ of grassland $(\mathrm{SH})$ was to be maintained. Although the use of the model in this context is probably premature it demonstrates the need and scope of use for this type of grazing models.

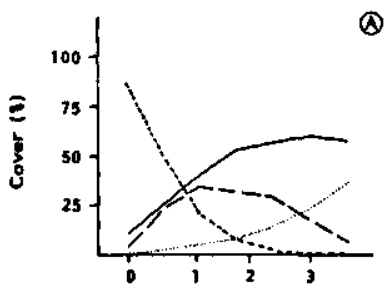

(ब)

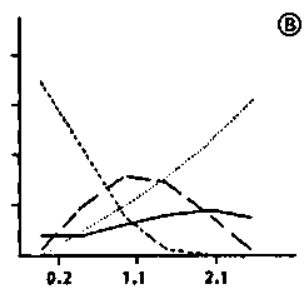

(B)
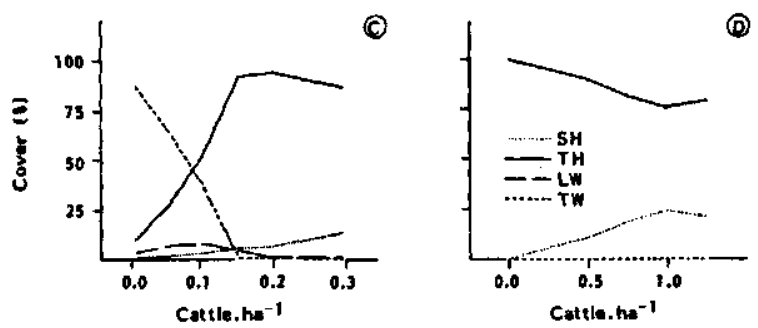

Fig. 12. Results of simulations with the PROCOS model for the Oostvaardersplassen area (see 5.3). The equilibria between the four macrostructural classes are shown, under different systems of cattle grazing: (a) seasonal grazing May-October; (b) seasonal grazing May-October, with 50 percent of the grasslands inundated from December to April; (c) continuous grazing, with inundation as for (b); (d) seasonal grazing May-October, with geese grazing ( 10 geese per hectare) from November to April. Note the difference in scale of the $x$-axes. The simulations ranged from no grazing by cattle to the maximum density possible.

\section{Further development, improvements}

The models MAT and PROCOS, outlined here, are relatively simple and still in an early stage of development. Modelling is an iterative process, whereby the output of simulations should be continuously checked against real values and the model adapted accordingly. There are reasons to continue with both MAT and PROCOS. The first model has the virtue of prediction using a relatively small number of parameters. The second model can provide a further insight in the processes taking place in the various grazing situations, and seems particularly suited to identify key-factors, e.g. with respect to the transitions from one structural class to an other. In PROCOS physiological parameters of the vegetation components and the grazers may have to be incorporated. MAT and PROCOS are, therefore, regarded complementary models. Further development has been considered and is now in progress. 
The modelling sofar has two main shortcomings:

1. the important spatial aspects are not yet included,

2. simulation of simultaneous grazing of more than one large herbivore is not yet possible; this aspect, however is of crucial importance, especially in the more natural grazing systems (cf. Drent \& Prins, this volume).

The first aspect is at present the major point of attention for MAT. For this model more specifically the following improvements could be made:

a) the density of herbivores should be incorporated as a continuum, rather than discrete classes (cf. Table 4.);

b) a number of vegetation qualities depends on the abiotic conditions of the terrain; such parameters should be accounted for in a simple way, e.g. in the parameter 'carrying capacity';

c) in many reserves grazing is seasonal or supplementary feed is supplied during the winter; the possibility of changing pressures within the year should be incorporated;

d) further a subdivision of the structural classes should be considered.

For PROCOS a number of realistic improvements could also be suggested:

a) a further subdivision could be made in the various structural classes e.g. phenological stages in the classes $\mathrm{SH}$ and $\mathrm{TH}$ : vegetative, flowering, etc.;

b) important abiotic variables directly influencing productivity should be incorporated;

c) incorporation of a regrowth factor after grazing, probably with a time lag;

d) inclusion of a herbaceous production component in the woody structural types, i.e. simulating grasses and forbs growing under trees;

e) incorporation of forage quality parameters which would greatly improve the degree of reality of the model with respect to the preference of herbivores;

f) incorporation of some key physiological parameters of the animal that determine the intake of food, in order to simulate properly the annual variation of the requirement.

\section{Summary and conclusions}

For most of Western Europe the climax vegetation is forest, but grazing animals can prevent this succession and create and maintain conditions conducive for other vegetation types, especially short grasslands and shrubland. Experience in The Netherlands has shown that grazing with large herbivores can develop and maintain the structural diversity of vegetation. There is strong evidence that this will, in due time, lead to increased species diversity, of both plants and animals. Grazing can be substituted for, and has advantages over, other practices such as mowing and cutting of shrubs and trees. For economic reasons, but in particular because grazing leads to spatial variation and higher species diversity, grazing with livestock at low densities is now used in several hundred conservation areas in The Netherlands. The changes in vegetation structure caused by grazing animals are slow and methods are needed to predict the consequences of grazing management. Two simple models are described that were developed for this purpose, enabling the simulation of changes in vegetation structure under different grazing regimes. The descriptive matrix model MAT is compact and relatively easy to apply with a low number of input parameters. All the controlling factors are condensed in one operator, the transition matrix. PROCOS is an analytical model in which the impact of large herbivores on the macrostructure of vegetation is approached by simulating the production of aerial phytomass and its consumption or destruction by the grazing and browsing animals.

The MAT model uses four macrostructural classes, in which different development phases can be distinguished, simulating the rate of succession (short herbaceous, tall herbaceous, low woody and tall woody). In the PROCOS model the same four macrostructural types are used for the output, but in this model the relative growth rate is used as the main factor in determining succession. Any terrain can be characterized in terms of the four classes. Grazing may lead to retrogression, steady state or retarded succession in 
the sequence of the four types as mentioned above.

Validation of the models is difficult, because of lack of historical data on grazing pressures and vegetation development. Both models have been applied to the reserve area Borkener Paradies, for which considerable data exist. This area has been summer grazed by cattle for many years. The results of the MAT and PROCOS simulations are reasonably well in agreement with the information on long-term development in the structure of the vegetation as derived from literature sources.

The models have an important demonstrationvalue for those involved in policy making, administration, and management practice. The longterm effects can be shown. The models illustrate that it may take many decades or centuries before an equilibrium is reached between the grazing system and the final structural diversity aimed at.

Finally some apparent shortcomings and possibilities for improvement are outlined. In particular the value of incorporating spatial pattern and mixed grazing is considered. Work along these lines is now in progress.

\section{Acknowledgements}

We thank J.P. Bakker, H.H.Th. Prins, R.A. Prins, P.A. Slim and S.E. van Wieren for critically reading an early draft of the paper. Their comments have been incorporated in the final version or will be used in the further development of the models. P.A. Slim kindly provided the unpublished data presented in Table 2 . The critical remarks and skilful editing of R.W. Snaydon considerably improved the final text.

\section{References}

Bakker, J.P., de Bie, S., Dallinga, J.H., Tjaden, P. \& de Vries, Y. (1983). Sheep grazing as a management tool for heathland conservation and regeneration in The Netherlands. J. appl. Ecol. 20: 541-560.

Bakker, J.P, de Leeuw, J. \& van Wieren, S.E. (1984). Micro- patterns in grassland vegetation created and sustained by sheep-grazing. Vegetatio 55: 153-161.

Breymeyer, A.I. \& van Dyne, G.M. (1980). Grassland, systems analysis and man. IBP 19, Cambridge University Press.

Burrichter, E., Pott, R., Raus, T. \& Wittig, R. (1980). Die Hudelandschaft 'Borkener Paradies' im Emstal bei Meppen. Abhandlungen aus dem Landesmuseum für Naturkunde zu Münster in Westfalen 42. Jahrgang 1980, Heft 4.

Centraal Veevoederbureau (1979). Verkorte tabel voedernotmen voor de landbouwhuisdieren en voederwaarde van veevoeders. Centraal Veevoederbureau in Nederland, Wageningen.

Christian, K.R. (1981). Simulation of Grazing Systems. In: F.H.W. Morley (Ed.) Grazing animals, World Animal Scjence vol. Bl. pp 361-377. Elsevier Scientific Publishing Company, Amsterdam, Oxford, New York.

Coughenour, M.B., McNaughton, S.J. \& Wallace, L.L. (1984). Simulation study of East-African perennial graminoid responses to defoliation. Ecol. Modelling 26: 177-201.

Eijsackers, H.J.P. (1983). Development of earthworm populations in abandoned arable fields under grazing management. In: J.E. Satchell (Ed.) Earthworm Ecology; from Darwin to vermiculture, pp 241-246. Chapman, London.

Hillegers, H.P.M. (1984). Begrazing met Mergelland schapen in Zuid-Limburg. De Levende Natuur 85: 178-184.

Hofmann, R.R. (1973). The Ruminant Stomach - Stomach Structure and Feeding Habits of East African Game Ruminants. East African Literature Bureau Nairobi, Kampala, Dar Es Salaam.

Hofmann, R.R. (1976). Zur adaptieven Differenzierung der Wiederkauer, Untersuchsergebnisse auf der Basis der vergleichenden funktionellen Anatomie des Verdauungstrakts. Der praktische Tierarzt 6: 351-358.

Jaspers, C.J. (1983). Bos- en struweelontwikkeling onder beweiding in het 'Borkener Paradies'. Report no. 724 Department of Nature Conservation, Agricultural University, Wageningen.

Jeffers, J.N.R. (1978). An introduction to systems analysis with ecological applications. Arnold, London.

Jeffers, J.N.R. (1982). Modelling. Outline studies in ecology. Chapman and Hall, London, New York.

Leeuw, J. de \& Bakker, J.P. (1986). Sheep-grazing with different foraging efficiencies in a Dutch mixed grassland. J. appl. Ecol. 23: 781-793.

Lotz, B. \& Poorter, H. (1983). Natuurtechnische begrazing; een aanzet tot een modelmatige benadering. RIN-rapport 83/2. Research lnstitute for Nature Management, Leersum, The Netherlands.

Noy-Meir, J. (1978). Grazing and production in seasonal pastures; analysis of a simple model. J. appl. Ecol. 15: 809-835.

Oosterveld, P. (1975). Beheer en ontwikkeling van natuurreservaten door begrazing. Natuur en landschap 29: 161-171.

Oosterveld, P. (1976). Integratie van voormalige landbouwgronden d.m.v. extensief graasbeheer met IJslandse pony's 
in de Baronie Cranendonck. Contactblad voor Oecologen 12: 99-109.

Oosterveld, P. (1979). Maaien, grazen of stuiven, via natuurbeheer naar meer natuur. Duin 2: 3-8.

Oosterveld, P. (1983). Eight years of monitoring of rabbits and vegetation development on abandoned arable fields grazed by ponies. Acta Zool. Fennica 174: 71-74.

Oosterveld, P. (1985). Grazing as a management tool in nature conservation - grazing management for the integration of formerly arable fields in reserve areas. In: Annual Report 1984 Research Institute for Nature Management, pp 29-32. Leersum, The Netherlands.

Parton, W.J. \& Risser, P.G. (1979). Simulated impact of management practices upon tallgrass prairie. In: N. French (Ed.) Perspectives in grassland ecology. Springer Verlag, New York.

Petterson, B. (1965). Gotland and Oland. Two limestone islands compared. Acta Phytogeogr. Suecica 50: 131-140.

Pratt, R.M., Putman, R.J., Ekins, J.R. \& Edwards, P.J. (1986). Use of habitat by free-ranging cattle and ponies in the New Forest, Southern England. J. appl. Ecol. 23: $539-557$.

Putman, R.J. (1986). Grazing in Temperate Ecosystems: Large Herbivores and the Ecology of the New Forest. Croom Helm, Beckenham.

Redetzke, K.A. \& van Dyne, G.M. (1976). A matrix model of a rangeland grazing system. J. Range Manage. 29: 425-430.

Rosen, E. \& Sjögren, E. (1973). Sheep grazing and changes of vegetation of the limestone heath of Oland. Zoon. Suppl. 1: $137-150$.

Sjögren, E. (1970). Short introduction to Oland especially with remarks on sheep grazing on the limestone heath. Mimeo, 7 pp.

Sonnema, M. (1974). Weidebouw; cultuur en gebruik van grasland. Stam-Robijns, Culemborg, The Netherlands.

Swartzman, G. (1980). Evaluation of ecological simulation models. In: S. Levin (Ed.) Mathematical modelling in biology and ecology, pp 230-267. Springer Verlag. New York.

Thalen, D.C.P. (1984a). Large mammals as tools in the conservation of diverse habitats. Acta Zool. Fennica 172: 159-163.

Thalen, D.C.P. (1984b). Begrazingsbeheer en begrazingsonderzoek: een ontwikkelingsschets. De Levende Natuur 85: $35-40$.

Van de Laar, J.A.J. \& Slim, P.A. (1979). Veranderingen in flora en vegetatie van de verlaten landbouwgronden in het CRM-reservaat Baronie Cranendonck na vijf jaar begrazing door IJslandse pony's (1972-1979). RIN-report 79/13, Leersum, The Netherlands.

Van de Veen, H.E. (1979). Food selection and habitat use in the Red Deer (Cervus elaphus L.). Ph. D. Thesis, University of Groningen.

Van de Veen, H.E. \& van Wieren, S.E. (1980). Van grote grazers, kieskeurige fijnproevers en opportunistische gelegenheidsvreters; over het gebruik van grote herbivoren bij de ontwikkeling en duurzame instandhouding van natuurwaarden. Rapport 80/11 Instituut voor Milieuvraagstukken, VU Amsterdam.

Van Wijngaarden, W. (1985). Elephants - Trees - Grass Grazers; relationships between climate, soil, vegetation, and large herbivores in a semi-arid savanna ecosystem (Tsavo, Kenya). ITC Publication Number 4. ITC, Enschede, The Netherlands.

Westhoff, V. (1971). The dynamic structure of plant communities in relation to the objectives of conservation. In: Duffey \& Watts (Eds.): The scientific Management of Animal and Plant Communities for Conservation, pp 3-14. Blackwell, Oxford, London and Edinburgh.

Westhoff, V. (1977). Botanical aspects of nature conservation in densely populated countries. In: A. Myawaki \& $R$. Tüxen (Eds.): Vegetation Science and Environmental Protection, p 369-374. Mazuren, Tokyo, 